\title{
The Participation of a Putative Cell Surface Receptor for Laminin and Fibronectin in Peripheral Neurite Extension
}

\author{
D. Bozyczko and A. F. Horwitz \\ Department of Biochemistry and Biophysics, University of Pennsylvania, School of Medicine, Philadelphia, \\ Pennsylvania 19104
}

\begin{abstract}
We have used the CSAT (cell substrate attachment) monoclonal antibody (Mab), which is directed against a putative laminin and fibronectin receptor, to examine its role in the adhesive phenomena of neurons. This antibody was previously found to disturb the adhesion of several classes of fibroblasts and muscle. Here we report its effects upon neuronal-substrate adhesion. Two sources of neurons were investigated - the dorsal root and ciliary ganglia. Both responded similarly. Neurons plated in the presence of the CSAT Mab did not adhere to the substratum and process formation was inhibited completely for at least 24$48 \mathrm{hr}$. In explant cultures, when neurons were first allowed to extend processes prior to addition of the CSAT Mab, the results depended on the particular substrate. With some substrates, the neurites bundled and detached from the substratum; with others, they retracted and regrew to form large fascicles or bundles of processes. In dissociated cultures that already had extended processes, neurites fasciculated and cell bodies aggregated in response to the presence of the CSAT Mab. The magnitude of this response varied, depending upon the substrate. The antigen was localized, using immunofluorescence, on neuronal cell bodies, axons, and growth cones. This distribution correlated with its biological effects on all parts of the neuron. The antigen was isolated from neuronal cultures by immunoaffinity purification. It migrated in the molecular weight range of $140 \mathrm{kDa}$ on reducing SDS-PAGE. This antigen is very similar to that isolated from fibroblasts, which is an integral membrane glycoprotein complex. The data presented implicate the participation of the CSAT antigen in neurite extension and fasciculation.
\end{abstract}

A central goal in neural development is to elucidate the mechanisms by which axons are guided to and recognize their target sites. Numerous studies on vertebrate and invertebrate systems have illustrated that the establishment of innervation patterns is a highly stereotyped and specific process (Bentley and Caudy, 1983; Goodman et al., 1984; Landmesser et al., 1983; Raper et al., 1983; Stirling and Summerbell, 1983). Most hypotheses propose that adhesive-receptor interactions, either between cell surface molecules with other cell surface molecules or with molecules comprising the extracellular matrix, contribute significantly to axonal outgrowth, guidance, and selective synapse for-

Received June 13, 1985; revised Aug. 30, 1985; accepted Sept. 3, 1985.

This work was supported by NIH Grant GM 23244, the H. M. Watts, Jr., Neuromuscular Disease Research Center, and NIH Cardiovascular Predoctoral Training Grant HL 07502. We thank Cindi Decker for her picture of the CSAT Mab effects on ciliary ganglia and Kim Duggan for her donation of the CSAT antigen from tendon fibroblasts. We also thank Dr. G. Bennett for her kind donation of the polyclonal antisera against neurofilament proteins, Dr. K. Knudsen for the polyclonal antisera against the CSAT antigen, and Dr. Louis Reichardt for his comments on the manuscript.

Correspondence should be addressed to A. F. Horwitz, Department of Biochemistry and Biophysics, University of Pennsylvania, School of Medicine, Philadelphia, PA 19104

Copyright (C) 1986 Society for Neuroscience $0270-6474 / 86 / 051241-11 \$ 02.00 / 0$ mation. Recently, several laboratories have identified putative cell surface adhesion molecules on neurons and have implicated them as factors participating in axonal guidance and target site recognition. The neural cell adhesion molecule (N-CAM), for example, appears to modulate the cell-cell interaction in neurite bundling by its transient expression during specific stages of neural development (Rutishauser and Edelman, 1980; Rutishauser et al., 1978; for reviews, see Edelman et al., 1983, and Rutishauser, 1983). It also appears to promote neuromuscular contact (Grumet et al., 1982; Rutishauser et al., 1983) and the elaboration of the retinotectal map (Buskirk et al., 1980; Thanos et al., 1984). The neural-glial (N-G)-CAM appears to be involved in migration of neuronal cells along radial glia in the CNS (Grumct and Edelman, 1985). L1 is another antigen, perhaps similar to N-G-CAM, that appears to contribute to neuralglia interactions as well (Schachner et al., 1983). Extracellular molecules with which neurons might interact have also been identified. They include laminin (Manthorpe et al., 1983; Rogers et al., 1983), fibronectin (Rogers et al., 1983, 1985), a proteoglycan complex with laminin (Lander et al., 1985), and macromolecular complexes called adherons (Cole and Glaser, 1984a; Cole et al., 1985; Schubert et al., 1983).

We have used the CSAT monoclonal antibody, which is directed against a putative cell surface receptor for laminin and fibronectin, to elucidate its role in axonal extension and guidance. This antibody has previously been shown to perturb the cell-substrate adhesive interaction of several classes of fibroblasts and muscle (Decker et al., 1984; Neff et al., 1982). It localizes in regions of cell-substrate adhesion (Damsky et al., 1985; Neff et al., 1982), and its purified antigen is a glycoprotein complex that interacts in vitro with laminin and fibronectin in a physiologically signiticant manner (Horwitz et al., 1985; Knudsen et al., 1985). Similar observations have been made using another monoclonal antibody, JG22, directed against the same antigenic complex (Chen et al., 1985; Greve and Gottlieb, 1982). Here we report that the CSAT antigen participates in the extension of neurites and modulates fasciculation in peripheral nerve cultures (Bozyczko et al., 1984a, b).

\section{Materials and Methods}

\section{Neuronal cell culture}

Dorsal root ganglia (DRG) were dissected from the lumbosacral region of 9- or 10-d-old chick embryos and immediately placed into ice-cold calcium- and magnesium-free PBS (CMF-PBS) containing $60 \mu \mathrm{g} / \mathrm{ml}$ glucose. For dissociated cultures, the ganglia were digested for $25 \mathrm{~min}$ at $37^{\circ} \mathrm{C}$ using CMF-PBS containing $0.025 \%$ trypsin (Gibco, Grand Island, NY) and $60 \mu \mathrm{g} / \mathrm{ml}$ glucose (100 explants $/ \mathrm{ml}$ digestion mixture). Digestion was terminated by adding $3.0 \mathrm{ml}$ of Dulbecco's modified Eagle's medium (DMEM) containing 10\% horse serum (Gibco), $6 \mu \mathrm{g} /$ $\mathrm{ml}$ L-glutamine, $40 \mu \mathrm{g} / \mathrm{ml}$ conalbumin (Sigma Chemical Co., St. Louis, MO), $30 \mu \mathrm{g} / \mathrm{ml}$ glucose, $20 \mu \mathrm{g} / \mathrm{ml}$ gentamycin, $1.25 \mu \mathrm{g} / \mathrm{ml}$ fungizone, and $50 \mathrm{ng} / \mathrm{ml}$ NGF (Calbiochem-Behring Diagnostics, La Jolla, CA). 
Figure 1. Effect of CSAT monoclonal antibody on neurite extension and fasciculation. Dorsal root ganglia explants were grown on Aclar coated with polyL-lysine and gelatin. The CSAT monoclonal antibody was added after $24 \mathrm{hr}$ in culture, at which time neurites had extended from the ganglion and onto the substratum. Photographs were taken of ganglia that were in culture for 48 hr. $A, 48 \mathrm{hr}$ control culture. $B, 48 \mathrm{hr}$ culture to which the CSAT monoclonal antibody was added after the ganglia were in culture for $24 \mathrm{hr}$.

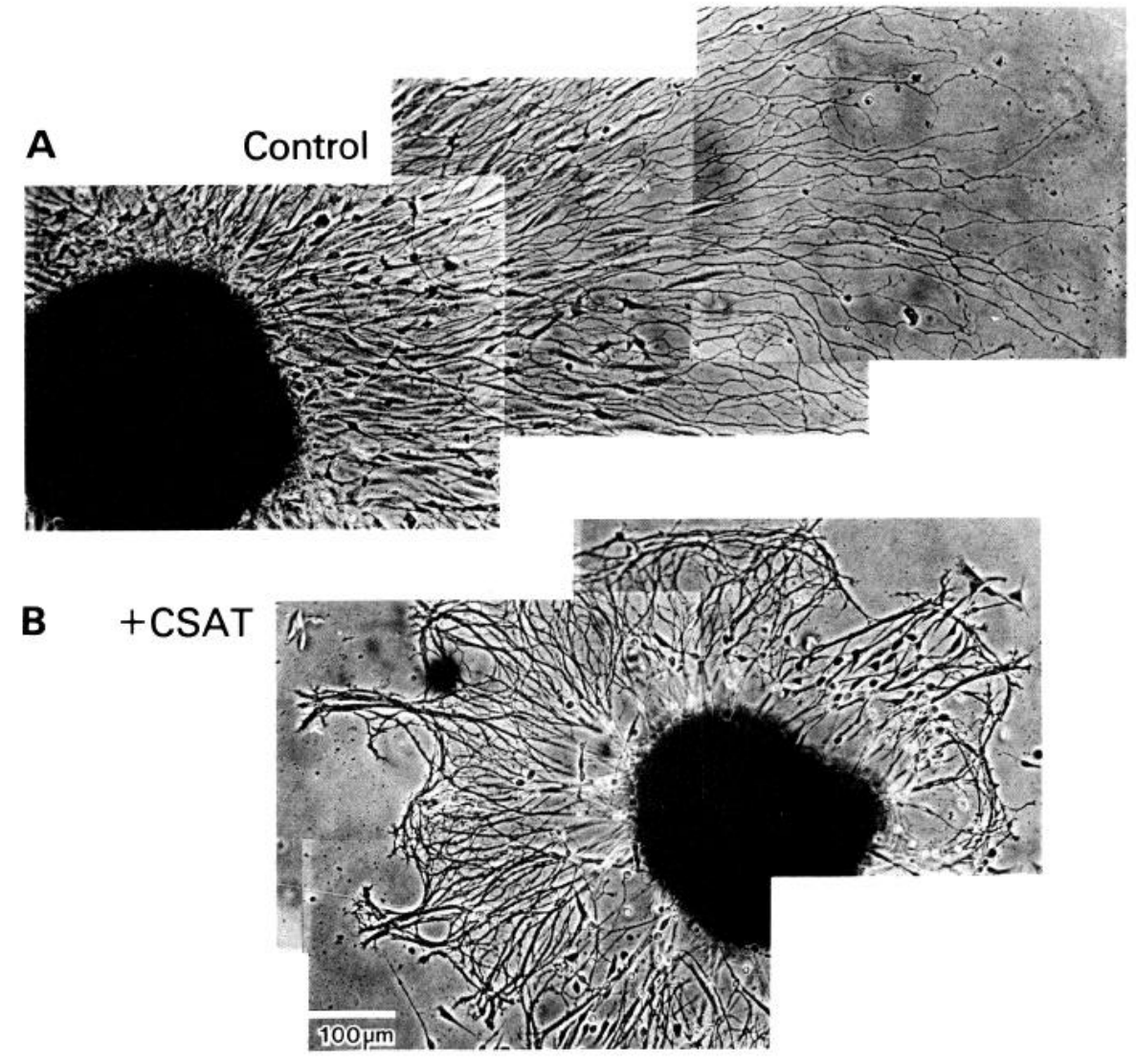

B 29 hours + CSAT

A 24 hours
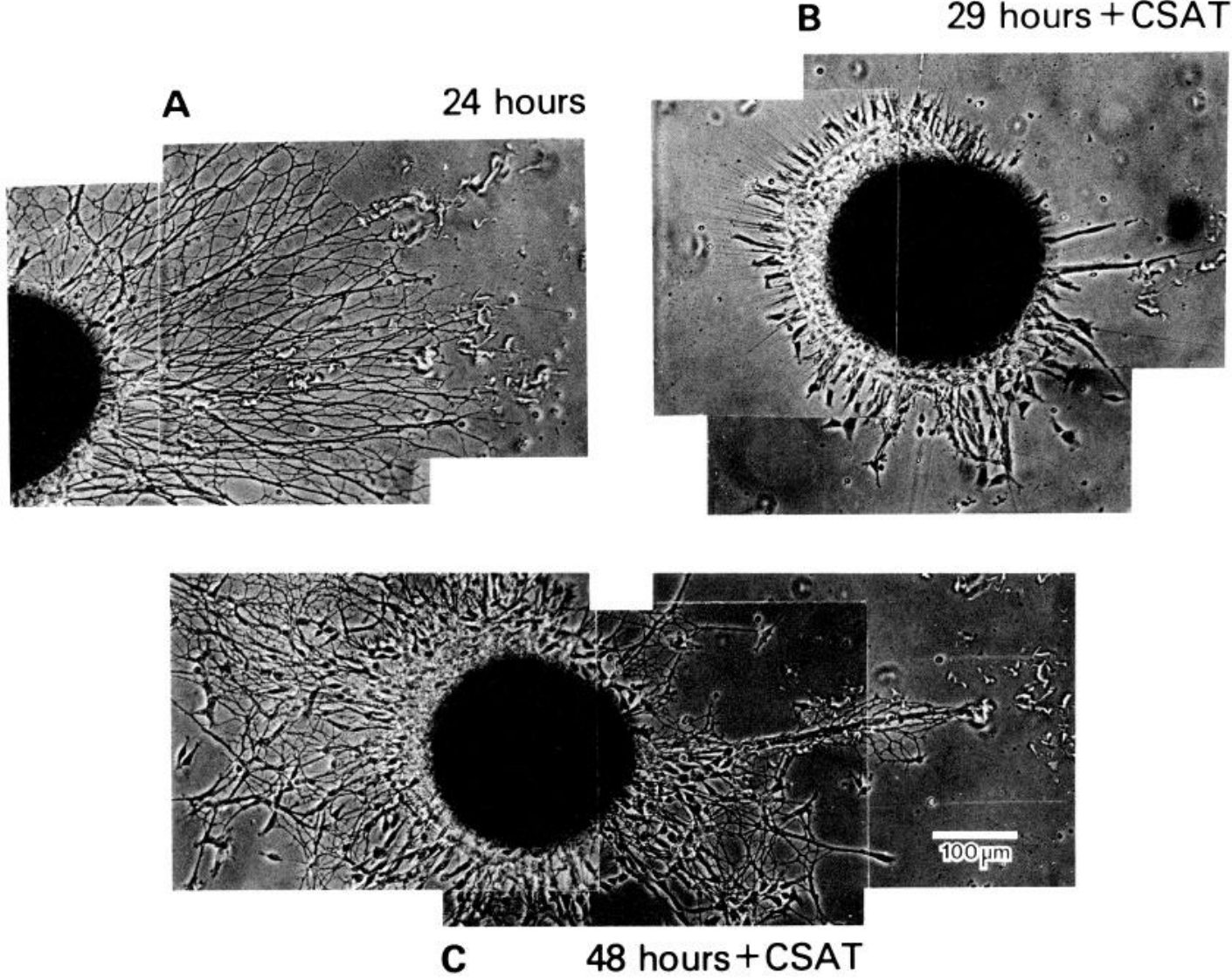
Explants were then gently pelleted at $140 \times g$ (IEC Clinical Centrifuge, Damon Co., Needham, MA) for $4 \mathrm{~min}$, resuspended in $2.0 \mathrm{ml}$ of the above media, triturated using a small-bore, fire-polished glass pipette, and passed through lens paper. To enrich for neuronal cells the suspension was preplated on Falcon tissue culture dishes (100-200 explant yield $/ 100 \mathrm{~mm}$ dish) for $1.5-2.0 \mathrm{hr}$. The cells remaining in suspension and those easily detached from the dish were harvested, centrifuged at $140 \times g$ (IEC Clinical Centrifuge) for $4 \mathrm{~min}$, and resuspended in an equal-parts mixture of modified SATO N1 media (Bottenstein et al., 1980) and fibronectin-free SATO heart-conditioned media (see below). Modified SATO N1 media contained DMEM, $6 \mu \mathrm{g} / \mathrm{ml} \mathrm{L-glutamine,} 40$ $\mu \mathrm{g} / \mathrm{ml}$ conalbumin, $30 \mu \mathrm{g} / \mathrm{ml}$ glucose, $40 \mathrm{~nm}$ progesterone (Sigma), 200 $\mu \mathrm{M}$ putrescine (Sigma), $5 \mu \mathrm{g} / \mathrm{ml}$ insulin, $5 \mathrm{ng} / \mathrm{ml}$ selenium, $100 \mu \mathrm{g} / \mathrm{ml}$ transferrin, $20 \mu \mathrm{g} / \mathrm{ml}$ gentamycin, $1.25 \mu \mathrm{g} / \mathrm{ml}$ fungizone, and $50 \mathrm{ng} / \mathrm{ml}$ NGF. For explant cultures the ganglia were dissected of rootlets and the connective tissue capsule before being transferred to a culture dish containing equal parts of modified SATO N1 media and fibronectinfree SATO heart-conditioned media. Each lot of NGF was assayed for optimal concentrations necessary to promote neurite outgrowth.

\section{Non-neuronal cell culture}

Non-neuronal cell populations were prepared by culturing the cells that readily and firmly attached to the Falcon tissue culture dishes during the preplating procedure (described above) in DMEM containing 10\% fetal calf serum, $6 \mu \mathrm{g} / \mathrm{ml} \mathrm{L}$-glutamine, $20 \mu \mathrm{g} / \mathrm{ml}$ gentamycin, and 1.25 $\mu \mathrm{g} / \mathrm{ml}$ fungizone. Cultures were grown to near confluency before use in the rounding and detachment assays.

\section{Preparation of SATO-defibronectinated heart-conditioned media}

Hearts obtained from 8- to 10-d-old chick embryos were immediately placed into cold CMF-PBS containing $60 \mu \mathrm{g} / \mathrm{ml}$ glucose. After atria were removed, ventricles were minced and allowed to incubate for $5 \mathrm{~min}$ at $37^{\circ} \mathrm{C}$ in CMF-PBS containing $60 \mu \mathrm{g} / \mathrm{ml}$ glucose. The buffer solution was then replaced with $4.0 \mathrm{ml}$ of CMF-PBS containing $0.05 \%$ trypsin and $60 \mu \mathrm{g} / \mathrm{ml}$ glucose. After $5 \mathrm{~min}$ of incubation at $37^{\circ} \mathrm{C}$, the tissue and cells were vigorously pipetted. The undigested tissue was allowed to settle, and the cell suspension was pipetted off and added to $3.0 \mathrm{ml}$ of DMEM containing $10 \%$ horse serum. The heart tissue was cycled through the above procedure three times. The cells were then centrifuged at $140 \times$ $g$ (IEC Clinical Centrifuge) for $4 \mathrm{~min}$, resuspended in DMEM containing $10 \%$ horse serum, $6 \mu \mathrm{g} / \mathrm{ml}$ L-glutamine, $30 \mu \mathrm{g} / \mathrm{ml}$ glucose, $40 \mu \mathrm{g} / \mathrm{ml}$ conalbumin, $20 \mu \mathrm{g} / \mathrm{ml}$ gentamycin, and $1.25 \mu \mathrm{g} / \mathrm{ml}$ fungizone, then passed through lens paper. Heart cells were plated $(15$ embryo yield $/ 100 \mathrm{~mm}$ plate) in $10.0 \mathrm{ml}$ of the above media onto Falcon tissue culture dishes coated with $0.1 \%$ gelatin. After incubating for $48 \mathrm{hr}$, the media was replaced with $30 \mathrm{ml}$ of SATO media (DMEM containing $6 \mu \mathrm{g} / \mathrm{ml} \mathrm{L-glu-}$ tamine, $30 \mu \mathrm{g} / \mathrm{ml}$ glucose, $40 \mu \mathrm{g} / \mathrm{ml}$ conalbumin, $20 \mu \mathrm{g} / \mathrm{ml}$ gentamycin, $1.25 \mu \mathrm{g} / \mathrm{ml}$ fungizone, and $1 \mu \mathrm{l} / \mathrm{ml}$ insulin-transferrin-selenium (ITS) premix (Collaborative Research, Waltham, MA). After incubating for $96 \mathrm{hr}$, the media was collected and freed of fibronectin by passing it two times over a $2.0 \mathrm{ml}$ gelatin Sepharose column equilibrated with HEPES-Hanks buffer, $\mathrm{pH}$ 7.4. Between passes, the column was eluted stepwise with $0.5 \mathrm{M}$ urea $(10.0 \mathrm{ml})$ and $4.0 \mathrm{M}$ urea $(10.0 \mathrm{ml})$. The absence of fibronectin in the SATO media was confirmed by SDS-PAGE. Fibronectin-free heart-conditioned medium (SATO DHCM) was sterile filtered and stored in $4.0 \mathrm{ml}$ aliquots at $-70^{\circ} \mathrm{C}$ until used.

\section{Preparation of cell culture substrata}

All neuronal cultures were grown and assayed on coated Aclar (33c-5 mil; Allied Corp., Morristown, NJ), whereas non-neuronal cultures were initially grown on uncoated Falcon culture dishes and then plated onto coated Aclar for assays. Prior to coating, Aclar was first cut to appropriate size ( 24 well dish insert) and then washed with $0.1 \%$ SDS and thoroughly rinsed in tapwater. It was then incubated overnight in concentrated nitric acid, and thoroughly rinsed in distilled water. Aclar was
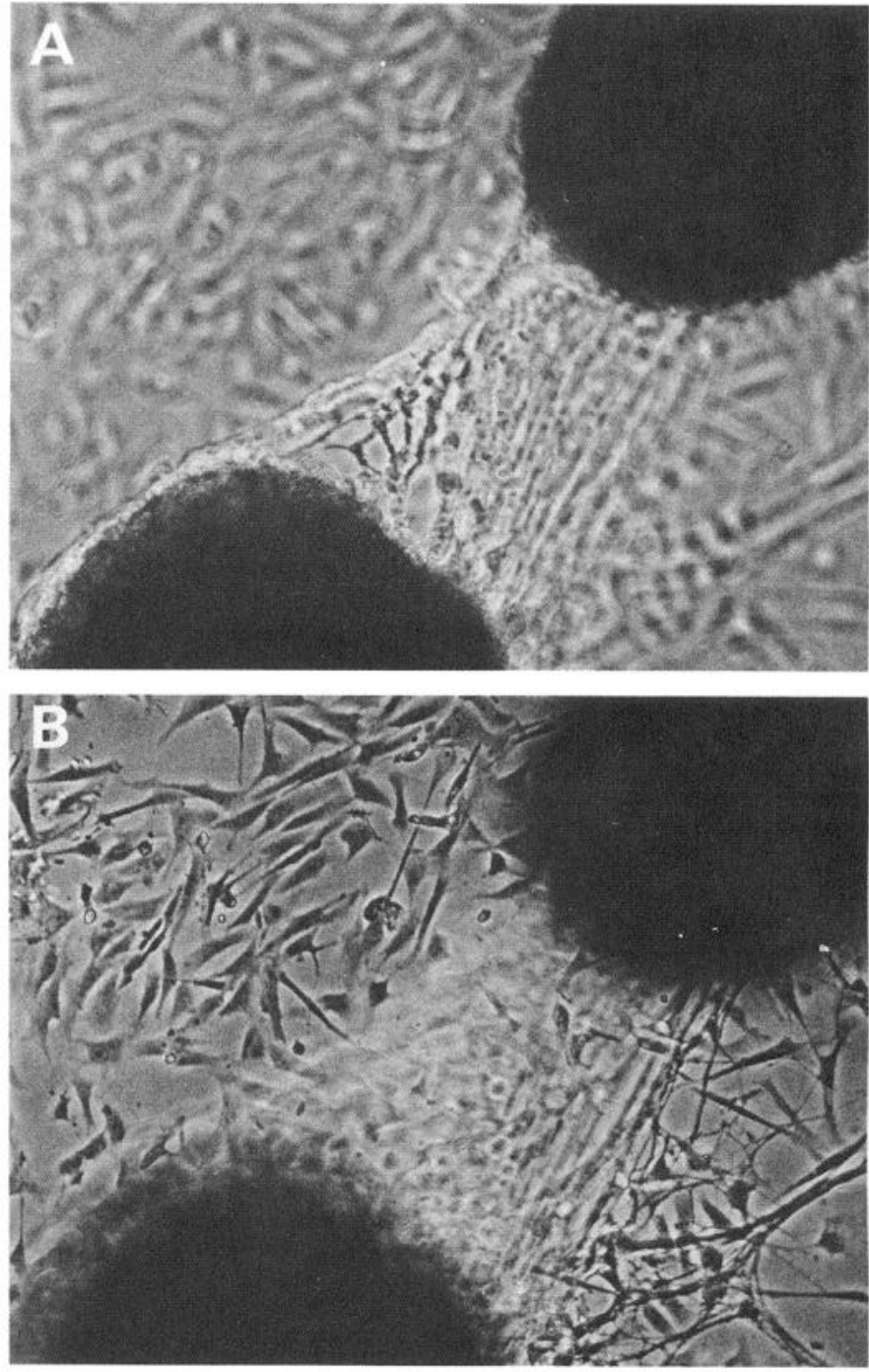

Figure 3. Effect of CSAT monoclonal antibody on dorsal root ganglion explants cultured on laminin-coated substrates. Dorsal root ganglion explants were grown on laminin-coated Aclar. The CSAT monoclonal antibody was added after the ganglia had been in culture for $24 \mathrm{hr}$, when neurites had extended out of the ganglion and onto the substratum. Photographs were taken after $48 \mathrm{hr}$ in culture. The explant culture shown in Fig. $2 A$ is a representative control for these experiments. $A$, Ganglia treated with the CSAT monoclonal antibody. Photograph taken in the focal plane of the ganglia, which are floating in suspension. Note the bundles of neurites connecting the ganglia. $B$, Same as above, except that the photograph was taken in the focal plane of the non-neuronal cells.

sterilized by first incubating 10-20 $\mathrm{min}$ in $95 \%$ ethanol and then incubating for $1 \mathrm{hr}$ under a UV light source. The Aclar was then coated with $0.1 \%$ gelatin for $2 \mathrm{hr}$ in the cold. The excess gelatin was aspirated and the surface allowed to dry. The gelatin-coated Aclar was then incubated overnight at $37^{\circ} \mathrm{C}$ with $1.0 \mathrm{ml}$ of solution containing $0.5 \mathrm{mg} /$ $\mathrm{ml}$ poly-L-lysine (Sigma, 15-30 M) in $0.12 \mathrm{M}$ borate (pH 8.3), $10 \mu \mathrm{g} /$ $\mathrm{ml}$ fibronectin (BRL, Gaithersburg, MD), or $10 \mu \mathrm{g} / \mathrm{ml}$ laminin (BRL).

Figure 2. Time course of the effect of the CSAT monoclonal antibody on neurite extension from dorsal root ganglion explants. Dorsal root ganglion explants were grown on Aclar coated with poly-L-lysine and gelatin. The CSAT monoclonal antibody was added after explants were in culture for $24 \mathrm{hr}$. Photographs were taken at 24, 29, and $48 \mathrm{hr}$. $A$, Explant culture at $24 \mathrm{hr}$ (before addition of the CSAT monoclonal antibody). B, Explant culture at $29 \mathrm{hr}$ ( $5 \mathrm{hr}$ after addition of the CSAT monoclonal antibody). $C$, Explant culture at $48 \mathrm{hr}(24 \mathrm{hr}$ after addition of the CSAT monoclonal antibody). 
Control
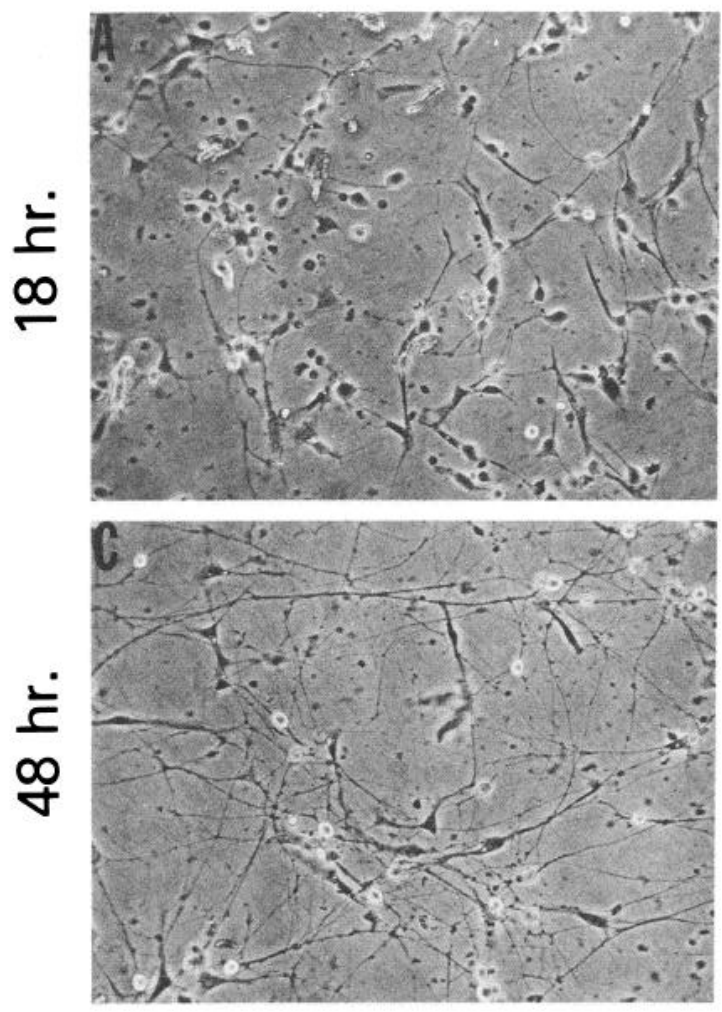
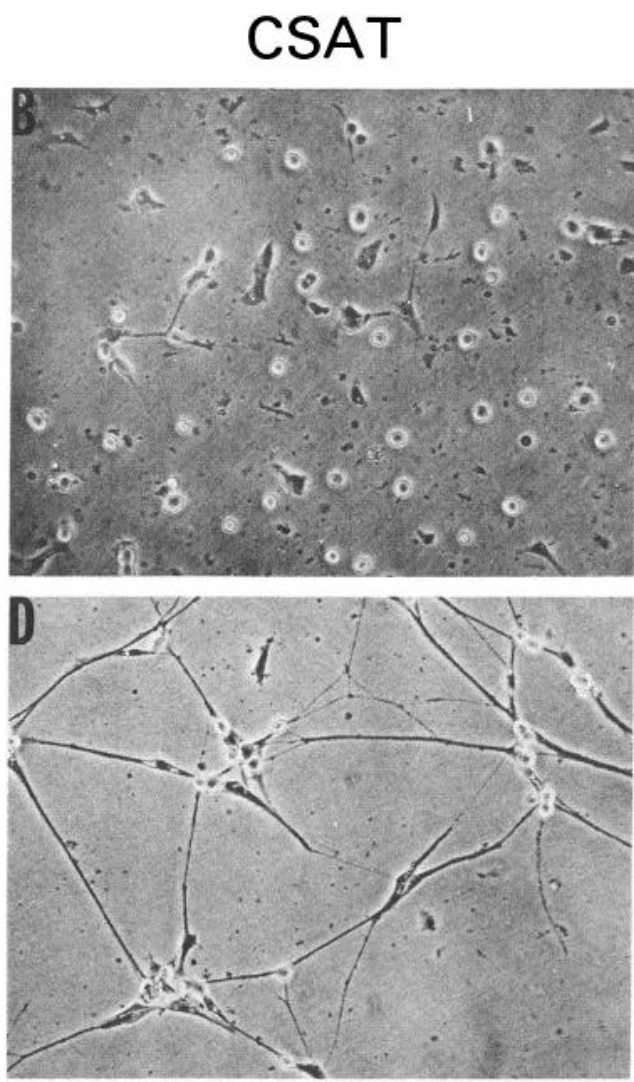

Figure 4. Effect of the CSAT monoclonal antibody on dissociated cultures of ciliary ganglia. Cultures of cells dissociated from ciliary ganglia were grown on tissue culture plates coated with poly-L-lysine. The CSAT monoclonal antibody was added either at the time of cell plating or at $24 \mathrm{hr}$, when neurons had extended fine processes out onto the substratum. Photographs were taken after 18 and $48 \mathrm{hr}$ in culture for both control and antibody-treated cultures. $A$ and $B$ show the inhibition of neurite extension by the CSAT monoclonal antibody added at the time of cell plating. The photograph was taken after neurons were in culture for $18 \mathrm{hr}$. $C$ and $D$ show neurite fasciculation and somal aggregation induced by addition of antibody after neurons were in culture for $24 \mathrm{hr}$ and photographed $24 \mathrm{hr}$ subsequently.

Solutions were then aspirated, and the coated Aclar was rinsed two times with distilled water and used immediately.

\section{Adhesion and fasciculation assays}

Dissociated neuronal cells or explants were plated on the desired substrates in equal parts of modified SATO N1 media and SATO DHCM containing $50 \mathrm{ng} / \mathrm{ml} \mathrm{NGF}$. The CSAT Mab was routinely added at a concentration of $20 \mu \mathrm{g} / \mathrm{ml}$, either at the time of cell plating or $24 \mathrm{hr}$ after (when the neurons had already adhered to the substratum and extended processes). Observations were made approximately $24 \mathrm{hr}$ after antibody addition, unless otherwise stated. Photographs were taken of the same field of view both prior to and after antibody addition. This was achieved by first focusing on the center of one well and lining up the phase rings; the rings were then left as set and subsequent wells were viewed by moving the plate until the rings realigned.

Non-neuronal cells were harvested by incubating cultures in Versene at $37^{\circ} \mathrm{C}$ for $15 \mathrm{~min}$. Cells were centrifuged at $140 \times g$ (IEC Clinical Centrifuge) for $4 \mathrm{~min}$, resuspended in SATO media (as above), and plated ( 40,000 cells/well using 24 well Falcon plates) either in the presence or absence of $20 \mu \mathrm{g} / \mathrm{ml}$ antibody. Observations were made 30 and 60 min after cell plating, and the number of spread cells were scored. To assay cell detachment from the substratum by the CSAT Mab, nonneuronal cells were allowed to incubate for $6-8 \mathrm{hr}$ after the initial harvesting and replating. The CSAT Mab was then added and the cultures were scored 1-24 hr later. Non-neuronal cells were also treated with cycloheximide $(10 \mu \mathrm{g} / \mathrm{ml})$ for $2-5 \mathrm{hr}$ prior to initial harvesting in some experiments.

\section{Immunofluorescent localization}

Dissociated cultures of neurons were grown for $16-20 \mathrm{hr}$ on either 0.5 $\mathrm{mg} / \mathrm{ml}$ poly-L-lysine and gelatin-coated Aclar or glass coverslips, in equal parts of modified SATO N1 medium and SATO DHCM. The coverslips were washed by dipping them five times in CMF-PBS at room temperature. The cells were fixed using $2.0 \%$ paraformaldehyde in PBS for $2 \mathrm{~min}$ at room temperature and rinsed by dipping 20 times in $0.15 \mathrm{M}$ glycine in PBS. The coverslips were then incubated for $1 \mathrm{hr}$ in PBS containing $10 \%$ goat serum, followed by incubation with a 1:1000 dilution of a polyclonal antisera (raised against the CSAT antigen) in PBS containing $10 \%$ goat serum. After extensive yet gentle rinsing in PBS, the coverslips were incubated for $1 \mathrm{hr}$ at room temperature in PBS containing $10 \%$ goat serum and $55 \mu \mathrm{g} / \mathrm{ml}$ TRITC goat anti-rabbit $\mathrm{Fab}_{2}$ fragments (Cappel Labs., West Chester, PA; heavy- and light-chain-specific). Immunofluorescent localization with either the polyclonal or monoclonal antibody CSAT resulted in the same staining pattern. The polyclonal antisera was routinely used for photographic purposes because of its brighter fluorescence staining. For staining with polyclonal antisera neurofilament $70 \mathrm{kDa}$ (NF70), cells were fixed (as above) and permeabilized using $0.5 \%$ Triton-X100 in CMF-PBS for 30 $\mathrm{min}$ at room temperature. The cells were then incubated in CMF-PBS containing $10 \%$ goat serum-PBS for $1-2 \mathrm{hr}$. All cells were extensively rinsed in PBS after application of secondary antibody and mounted onto glass slides using Immu-mount (Shandon Co., Sewickley, PA). The polyclonal antisera were kindly provided by Dr. K. Knudsen of the Wistar Institute, Philadelphia, PA. Neurofilament $70 \mathrm{kDa}$ antisera were kindly provided by Dr. G. Bennett of the Department of Anatomy, University of Pennsylvania School of Medicine, Philadelphia, PA.

\section{Antigen isolation}

Dissociated cultures of neurons were prepared as described above and cultured in equal parts of modified SATO N1 medium and SATO DHCM (250 explant/100 mm dish). Cells were grown on poly-L-lysine and gelatin-coated Aclar. After 16-24 hr, the plating media was replaced with $5.0 \mathrm{ml}$ of labeling media containing $250 \mu \mathrm{Ci} 35-S$-methionine. Labeling media consisted of methionine-free modified SATO N1 media. 

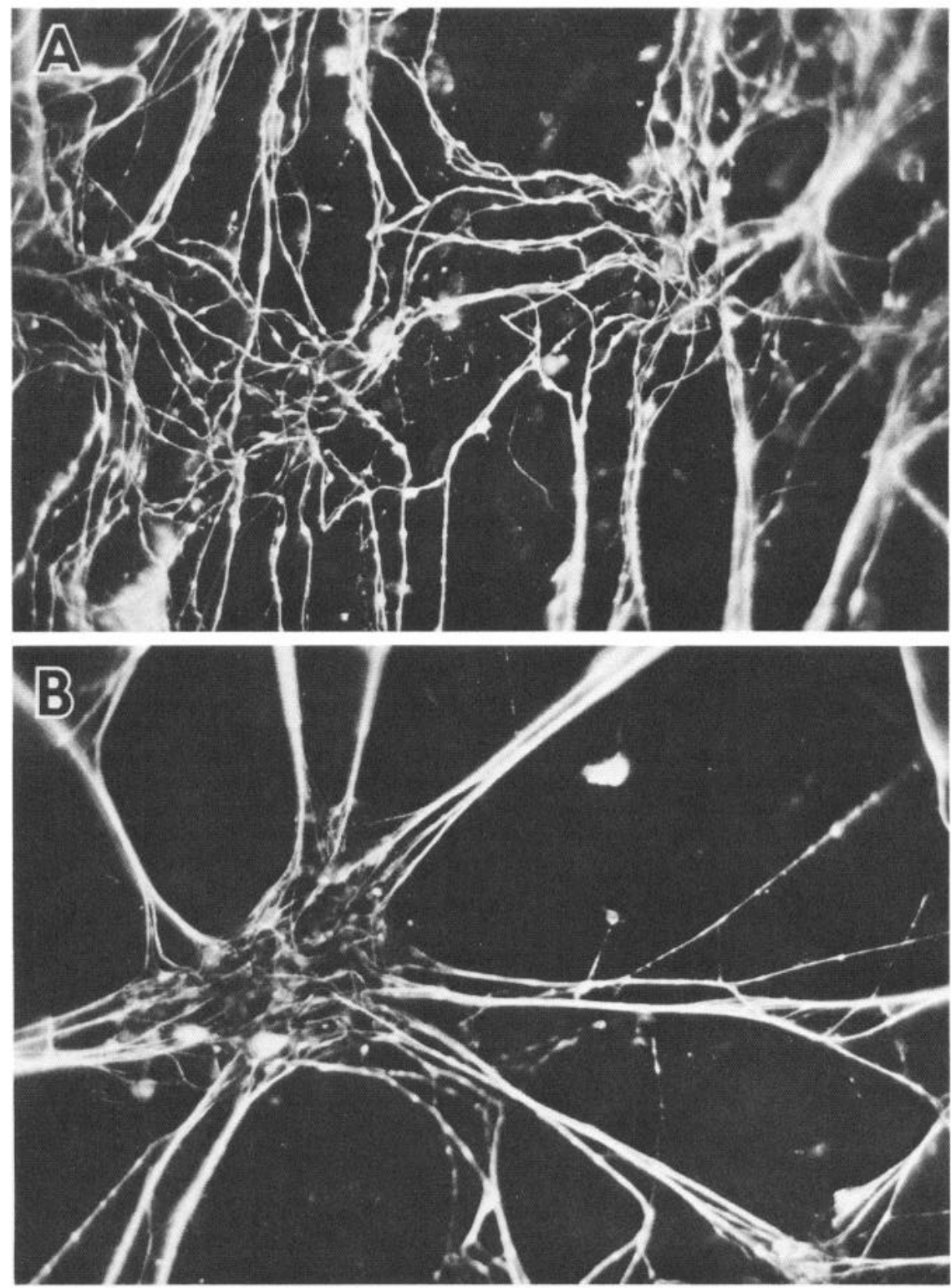

Figure 5. Immunofluorescence visualization of neurons in control and CSAT monoclonal antibody treated dissociated DRG cultures using a polyclonal antisera made against the neurofilament $70 \mathrm{kDa}$ protein (NF70). Cultures of cells dissociated from dorsal root ganglia were grown on Aclar coated with poly-L-lysine and gelatin. The CSAT monoclonal antibody was added after cells were in culture for $24 \mathrm{hr}$. At $48 \mathrm{hr}$, cultures were processed for immunofluorescent localization. The cells were fixed, permeabilized, and incubated with a rabbit polyclonal antisera made against NF70. Rabbit IgGs specific for NF70 were detected using rhodamine-conjugated goat anti-rabbit $\mathrm{Fab}_{2}$ fragments. $A$, Control culture at $48 \mathrm{hr}$. $B$, Culture to which the CSAT monoclonal antibody was added at $24 \mathrm{hr}$.
Neurons were incubated for $24 \mathrm{hr}$ in the presence of isotope. To harvest, labeled neurons were incubated for $5 \mathrm{~min}$ at $37^{\circ} \mathrm{C}$ in Versene containing $0.1 \mathrm{M}$ phenylmethylsulfonyl fluoride (PMSF; Sigma). The surfaces of the culture dishes were gently rinsed, removing the neurons and leaving contaminating non-neuronal cells attached to the dish. Antigen extraction and purification followed the procedure described previously, except that acetone precipitation was omitted and $0.15 \mathrm{M} \mathrm{NaCl}$ was added to all buffers (Decker et al., 1984; Neff et al., 1982). Throughout the isolation, the following protease inhibitors were included in all buffers: $1.0 \mathrm{~mm} O$-phenanthroline (Sigma), $1 \mu \mathrm{g} / \mathrm{ml}$ leupeptin (Sigma), $0.1 \mu \mathrm{g} /$ $\mathrm{ml}$ pepstatin (Sigma), and $0.1 \mathrm{~mm}$ PMSF. Affinity-purified antigen was electrophoresed on $7.0 \%$ SDS-PAGE (under both reducing and nonreducing conditions), transferred to nitrocellulose, and incubated with Kodak X-Omar film (Eastman Kodak, Rochester, NY) for 2-3 weeks.

\section{Preparation of Fab fragments}

Fab fragments of the CSAT Mab antibody were prepared essentially as described by Parham (1983) for a Balb/c mouse, species IgG2b. The CSAT Mab, at a concentration of $1 \mathrm{mg} / \mathrm{ml}$, was dialyzed for $12 \mathrm{hr}$ at $4^{\circ} \mathrm{C}$ against $0.1 \mathrm{~m}$ sodium acetate, $\mathrm{pH} 4.35$. Pepsin (Cooper Biomedical Worthington Division, Malvern, PA; 2480 units $/ \mathrm{mg}$ ), at a concentration of $5.8 \mu \mathrm{g} / \mathrm{ml}$, was added to yield an IgG: pepsin mole ratio of $40: 1$. The reaction mixture was gently shaken at $37^{\circ} \mathrm{C}$ for $18-20 \mathrm{hr}$. To terminate the digestion, the $\mathrm{pH}$ of the reaction mixture was raised to 7.0 using $2.0 \mathrm{M}$ Tris buffer. The solution was then dialyzed for $12 \mathrm{hr}$ at $4^{\circ} \mathrm{C}$ against Britton-Robinson buffer ( $28.5 \mathrm{~mm}$ citric acid, $29 \mathrm{mM} \mathrm{KH}_{2} \mathrm{PO}_{4}, 5.26$ $\mathrm{gm} /$ liter barbitol, and $18.8 \mathrm{~mm}$ boric acid) at $\mathrm{pH} 8.5$ and passed over a protein A Sepharose column. The wash and eluant at pH 3.5 were each dialyzed for $12 \mathrm{hr}$ at $4^{\circ} \mathrm{C}$ against distilled water, lyophilized, and analyzed by SDS-PAGE. Fab and smaller fragments were recovered in the wash, whereas whole IgG, Fab/c, and Fc fragments were recovered in the $\mathrm{pH} 3.5$ eluant. The activity of the Fab fragments was assayed by myoblast rounding (Neff et al., 1982).

\section{Results}

\section{Effects of the CSAT Mab on DRG explants}

We have assayed the effects of the CSAT monoclonal antibody on the adhesion and process extension of primary DRG explant cultures. After $48 \mathrm{hr}$ in culture, explants of DRG displayed numerous fine processes that extended radially onto the substrate (Fig. 1 $A$ ). The processes and growth cones appeared primarily as individual entities rather than in bundles or fascicles. The addition of the CSAT Mab at the time of plating inhibited adhesion of the ganglia and there was no process outgrowth for 

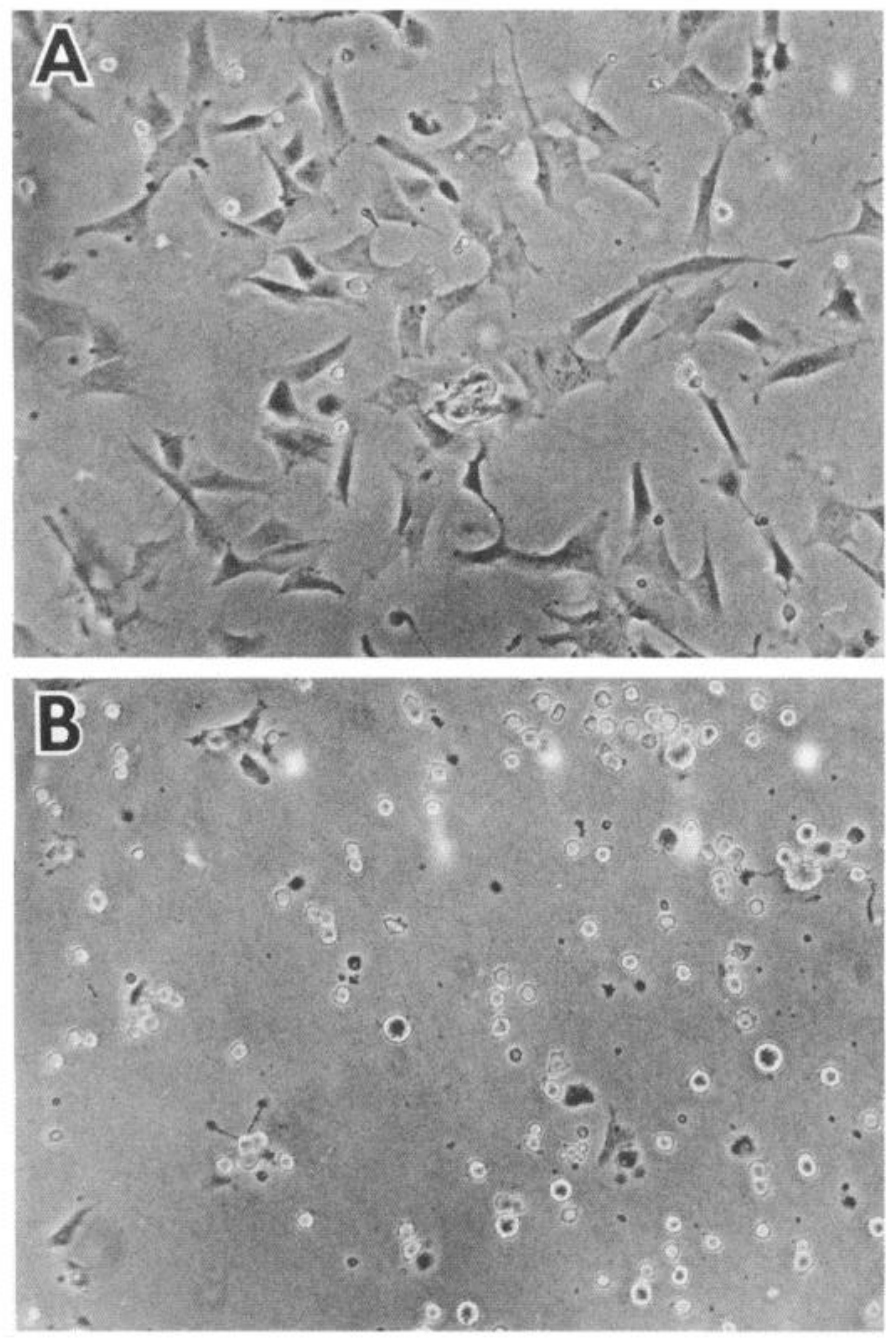

Figure 6. Effect of the CSAT monoclonal antibody on adhesion of non-neuronal cells. Non-neuronal cells were obtained from cultures of cells derived from preplated dissociated DRG cells. The preplates were harvested using Versene and plated in the presence or absence of the CSAT monoclonal antibody onto laminin-coated Aclar. Photographs were taken $1 \mathrm{hr}$ after plating. $A$, Control culture. $B$, Culture of cells plated in the presence of the CSAT monoclonal antibody.

at least 24-48 $\mathrm{hr}$ (not shown). The addition of the CSAT Mab to explant cultures at $24 \mathrm{hr}$, after which processes had begun to extend, produced an inhibition of neurite extension and a bundling of neurites into fascicles (Fig. $1 B$ ). An examination of the time course of the neurite response to the CSAT Mab showed that the growth cones and neurites retracted to the ganglia within $5 \mathrm{hr}$ after antibody addition (Fig. $2 B$ ). In the continued presence of the CSAT Mab, the processes subsequently re-extended, forming large fascicles (Fig. $2 C$ ). At the distal ends of the fascicles, the growth cones of neurites fanned out upon the substratum. These observations refer specifically to the effects of the CSAT Mab on explants that were cultured on a surface coated with poly-L-lysine and gelatin.

When the wells were coated with either laminin or fibronectin, and the antibody was added at plating, the extension of processes was also inhibited. When the CSAT Mab was added to cultures in which processes had extended, and the cells were visualized $24 \mathrm{hr}$ subsequently, the neurites appeared in bundles. However, in contrast to the observations on poly-L-lysine, the ganglia were generally detached from the substratum and appeared suspended as a network of ganglia interconnected by the neurite fascicles (Fig. 3).
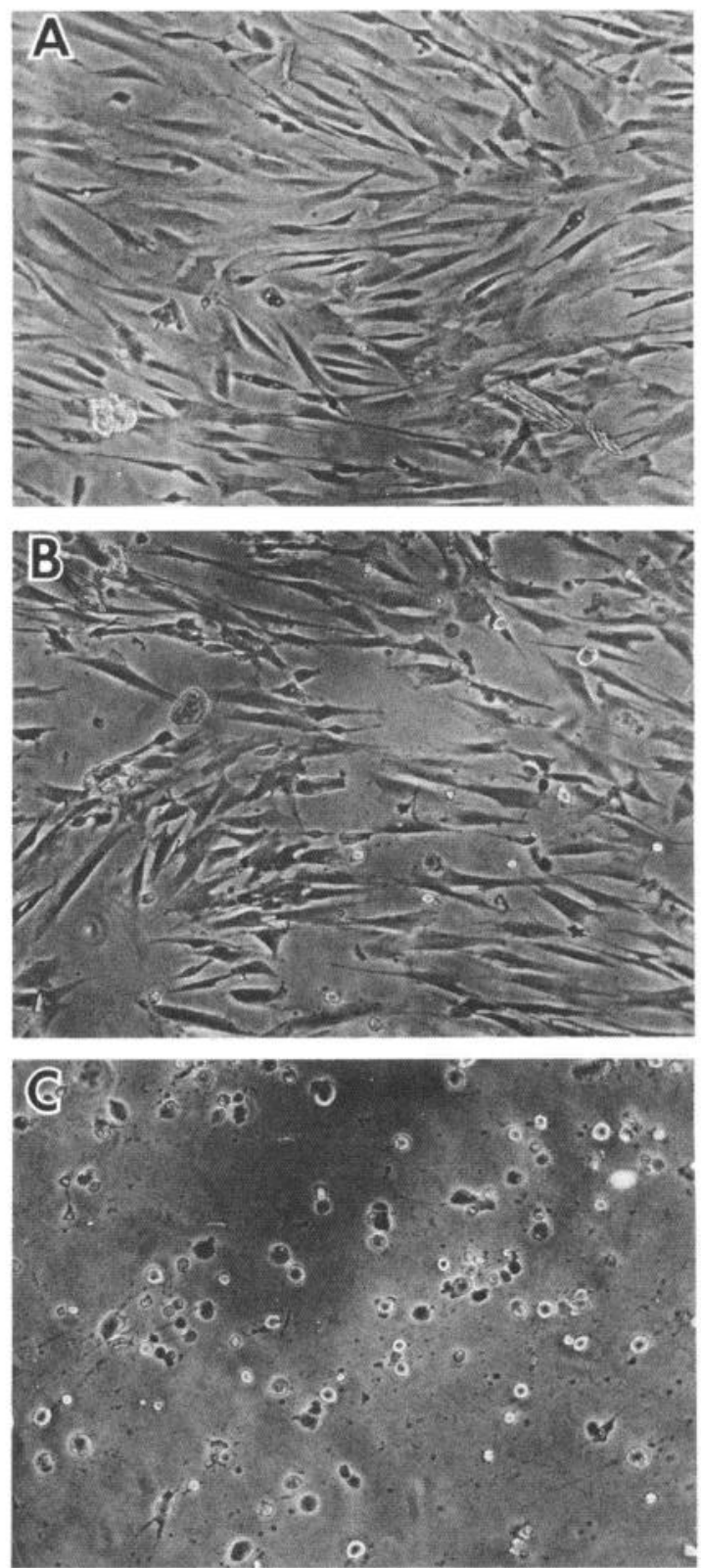

Figure 7. Effect of the CSAT monoclonal antibody on non-neuronal cells treated with cycloheximide. Cultures of cells dissociated from dorsal root ganglia were grown on laminin-coated Aclar. After $24 \mathrm{hr}$, cultures were treated with Versene for $5 \mathrm{~min}$. Detached neurons were rinsed from the cultures. The remaining non-neuronal cells were grown for an additional $12 \mathrm{hr}$. The cells were then incubated with cycloheximide for $4 \mathrm{hr}$ before addition of the CSAT monoclonal antibody. $A$, Control culture. $B$, Culture $24 \mathrm{hr}$ after antibody addition. $C$, Culture $48 \mathrm{hr}$ after antibody addition.

\section{Effects of the CSAT Mab on dissociated neuronal cultures}

We have also examined the effects of the CSAT Mab on dissociated cultures of chick ciliary and dorsal root ganglia. In general, both cell types responded similarly. The presence of antibody at the time of cell plating inhibited cell adhesion and process extension (Fig. 4, $A$ and $B$ ). After neurons have adhered to the substratum and extended processes, the addition of the CSAT Mab induced a bundling of the processes, as described above, for the explant cultures. However, the presence of the CSAT Mab also induced an aggregation of the neuronal cell bodies (Fig. 4, $C$ and $D$ ). These effects on the neuronal cells were seen more clearly using cultures stained with antibodies 
against the $70 \mathrm{kDa}$ neurofilament protein. This antisera is specific for neurons, and it thus allows selective observation of the change in neuronal morphology and associations. In control cultures, the neurites appeared as fine processes extended along the substratum (Fig. $5 A$ ). In cultures treated with the CSAT Mab the individual neurites were clearly seen in fascicles that interconnected aggregates of cell bodies (Fig. $5 B$ ).

The effects of the CSAT Mab on cells growing on different substrates were also examined. The magnitude of the response was a function of the particular substrate employed. The cell morphology was perturbed most dramatically with cells adhering to laminin and gelatin; cell morphology on poly-L-lysine was perturbed the least; and that on fibronectin lay between these two extremes. When the antibody was present at the time of plating, less than $5 \%$ of the total cell population adhered to laminin- or gelatin-coated substrates within $24 \mathrm{hr}$; some (40\%) of the cells loosely adhered to substrates coated with fibronectin; and $80 \%$ adhered to substrates coated with poly-L-lysine. This was assayed by the ease with which the cells could be washed off the coated Aclar with a stream of media. The extension of processes for cells plated on all substrates tested in the presence of the antibody was inhibited for the first 24-48 $\mathrm{hr}$; i.e., $97+$ $8 \%, 84+2 \%, 100+0 \%$, and $95+7 \%$ of the cells did not extend processes within $24 \mathrm{hr}$ on laminin, fibronectin, gelatin, and polyL-lysine substrate, respectively. After $48 \mathrm{hr}$ in culture, clusters of cell bodies were seen adhering to all substrates tested, and bundles of processes were seen connecting the somal aggregates. This effect was not observed when the CSAT Mab was replenished every $24 \mathrm{hr}$. In this protocol, the cells did not adhere to the substrate and remained in suspension. The bundling of neurites or fasciculation was most pronounced on laminin and gelatin, then fibronectin, and, lastly, poly-L-lysine. (The relative response to the CSAT Mab was assayed by estimating the fraction of processes residing in fascicles.) It is important to note that cells did not adhere to uncoated Aclar substrates either in the presence or absence of the CSAT Mab.

These effects of CSAT on neuronal adhesion were highly specific and noncytotoxic. Other antibodies that react with neuronal membrane antigens did not produce the same response as did the CSAT Mab. The cell-cell adhesive interactions involved in fasciculation and somal aggregation were also not detectably affected by the CSAT Mab, but in fact were promoted by it. The neurons remained viable in the presence of the CSAT Mab, as revealed by their ability to re-extend processes after an initial inhibition. Finally, the aggregation and fasciculation phenomena were also observed using either native, bivalent CSAT Mab, or Fab fragments derived from the neuron, demonstrating that they did not arise by antibody-mediated cross-linking.

\section{Effects of the CSAT Mab on non-neuronal cells}

We have also examined the effects of the CSAT Mab on nonneuronal cells present in neuronal cell cultures. Populations of these cells were obtained by culturing the cells derived from preplating dissociated ganglia. The cells from $80 \%$ confluent cultures were removed with EDTA and plated onto coated Aclar substrates. When plated in the presence of the CSAT Mab, $80 \%$ of the non-neuronal cells adhered to the poly-L-lysine substrate within an hour; $40 \%$ of the cell population was spread. Less than $10 \%$ of the total population adhered to the laminin, fibronectin, or gelatin substrates within this time period. During the $1-2 \mathrm{hr}$ time interval, $80-90 \%$ of the cells had adhered to the fibronectin substrate, but $50 \%$ of the cells remained in suspension on both the laminin and gelatin substrates. Figure 6 shows the inhibitory effect of the CSAT Mab on non-neuronal cellsubstrate adhesion when added at the time of cell plating. If the CSAT Mab was added 6-8 $\mathrm{hr}$ after cells had adhered to the substrates, less than $10 \%$ detachment was observed over a 96 $\mathrm{hr}$ time period. When cells were preincubated in the presence

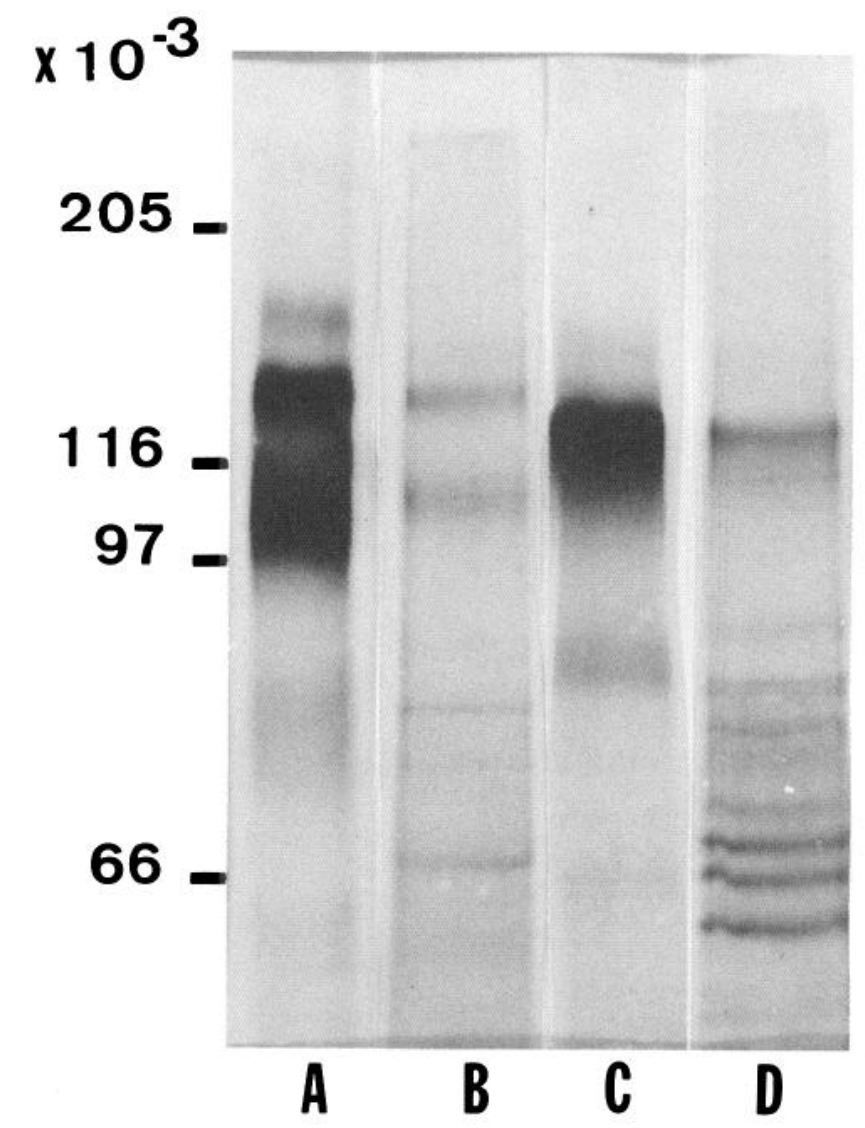

Figure 8. Autoradiogram of SDS-PAGE profiles of the CSAT antigen isolated by monoclonal antibody affinity chromotography from tendon fibroblasts $(A, C)$ and dorsal root ganglia neurons $(B, D)$. Both tendon fibroblasts and DRG neurons were grown in the presence of $35-S$ methionine, extracted with NP40, and fractionated by monoclonal antibody affinity chromatography. Samples were analyzed by SDS-PAGE in the presence $(C, D)$ and absence $(A, B)$ of reducing agents.

of cycloheximide prior to antibody addition, $80-90 \%$ of the cells detached. These cells appeared to pull up from the substrate at their edges by $24 \mathrm{hr}$, but did not become completely detached for $48 \mathrm{hr}$ (Fig. 7).

\section{Purification of the CSAT antigen}

The CSAT antigen has been purified from fibroblasts using antibody affinity chromatography (Neff et al., 1982). The antigen migrated as a broad band at $140 \mathrm{kDa}$ upon reducing SDS-PAGE. When run under nonreducing conditions, the antigen resolved into three distinct polypeptides. The three bands are glycoproteins and do not show substantial homology; they have the properties of integral membrane proteins and appear to reside as an oligomeric complex (Knudsen et al., 1985). Very similar antigens have been isolated from other cell types (Decker et al., 1984). The antigen isolated from neuronal cultures has essentially the same properties on SDS-PAGE gels as does the antigen isolated from fibroblasts (Fig. 8). It runs in the range of $140 \mathrm{kDa}$ upon reducing SDS-PAGE, and resolves into three polypeptides when run under nonreducing conditions. It is not clear at this time whether all of the bands comprising the CSAT antigen isolated from fibroblasts are also present in the antigen isolated from neurons. The presence of the lower molecular weight bands varied among different preparations and most likely arose from proteolysis, which seems to be a greater problem in the neuronal extracts. The small quantities of material available from the neurons hinder a careful comparison of the fibroblast and neural antigen. 
Figure 9. Localization of the CSAT antigen on a cultured dorsal root ganglion neuron. Neurons were grown for $16-20 \mathrm{hr}$ in culture on poly-L-lysine and gelatin-coated Aclar, fixed, and incubated with a polyclonal antisera raised against the affinity-purified CSAT antigen. The polyclonal antibodies were detected using rhodamine-conjugated goat anti-rabbit $\mathrm{Fab}_{2}$ fragments. $A$, Phase contrast. $B$, Rhodamine optics.
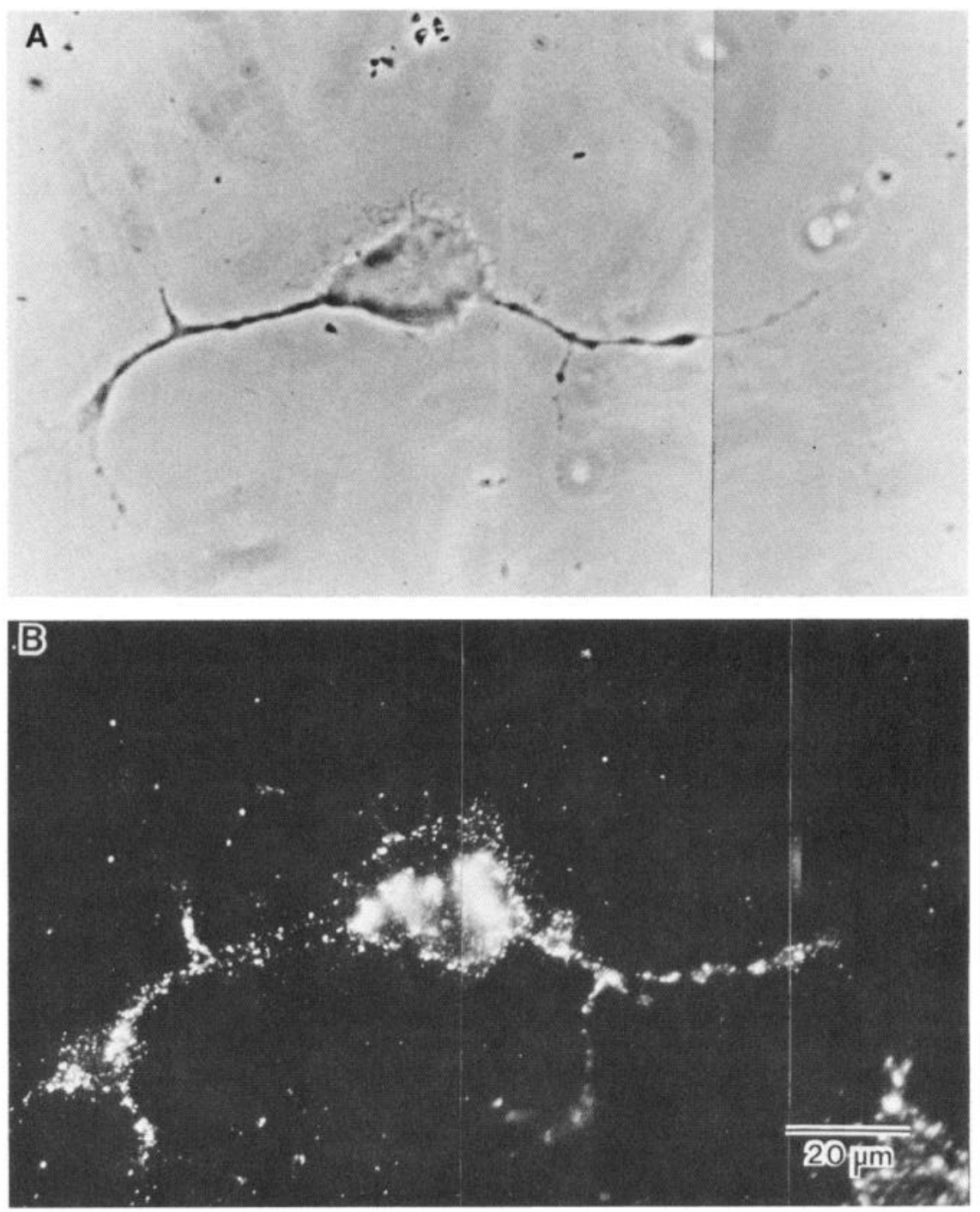

\section{Localization of the CSAT antigen on neuronal cells}

The CSAT antigen was localized on cultured neurons using two specific reagents: (1) the CSAT Mab and (2) a polyclonal antibody raised against the affinity-purified antigen. The antigen resides in a punctate distribution on all parts of the neuron, i.e., the soma, axon, and growth cone (Fig. 9). A close examination of the growth cone reveals antigen extending out on the microspikes (Fig. 10). This ubiquitous distribution of the antigen suggests that it participates in the adhesion of all neuronal parts rather than only in the adhesion of a specialized region. The antigen is also present, in a punctate distribution, on the nonneuronal cells present in these cultures. In cross sections of DRG from 8-d-old embryos, the antigen is confined to the cell surface region and thus outlines individual cell bodies. It is also present in the rootlets extending to and from the ganglion (not shown).

\section{Discussion}

We have used the CSAT Mab, which is directed against an adhesion-related cell surface antigen, to examine the role of this antigen in the adhesive phenomena of neurons. This antigen plays a very significant, if not dominant, role in the extension of peripheral axonal processes. Neurons plated in the presence of the CSAT Mab do not adhere to the substratum and process formation is completely inhibited for at least $24-48 \mathrm{hr}$. When neurons are first allowed to extend processes prior to the ad- dition of the CSAT Mab, the results depend on the particular substrate. With some substrates, neurites detach from the substratum, whereas with others, they retract and regrow to form large bundles of processes. The CSAT Mab does not appear to disrupt the cell-cell interaction involved in axonal fasciculation and, in fact, appears to promote it. The biological effects of the antibody, along with the localization of the antigen on neurons, suggests that the antigen participates in the adhesion of the entire neuron rather than in that of a single substructure, like the soma or growth cone.

Some preparations contain significant numbers of non-neuronal cells that often interact with the neurons. Several observations suggest that these cells do not appear to be the locus of the apparent effect of the CSAT Mab on the neurons. First, in the DRG explant cultures, the axons, which retract completely in response to the CSAT Mab, extend far beyond the nonneuronal cells residing in the near vicinity of the explant. Second, the antibody does not alter the adhesion of the non-neuronal cells during the time course of these experiments. And third, in cultures containing relatively few non-neuronal cells, not all of the neurons interact with them, yet all are affected by antibody.

The substrate-dependent effects of the CSAT Mab reported here for neurons parallel previous observations in fibroblasts (Decker et al., 1984). The adhesion of tendon fibroblasts to 

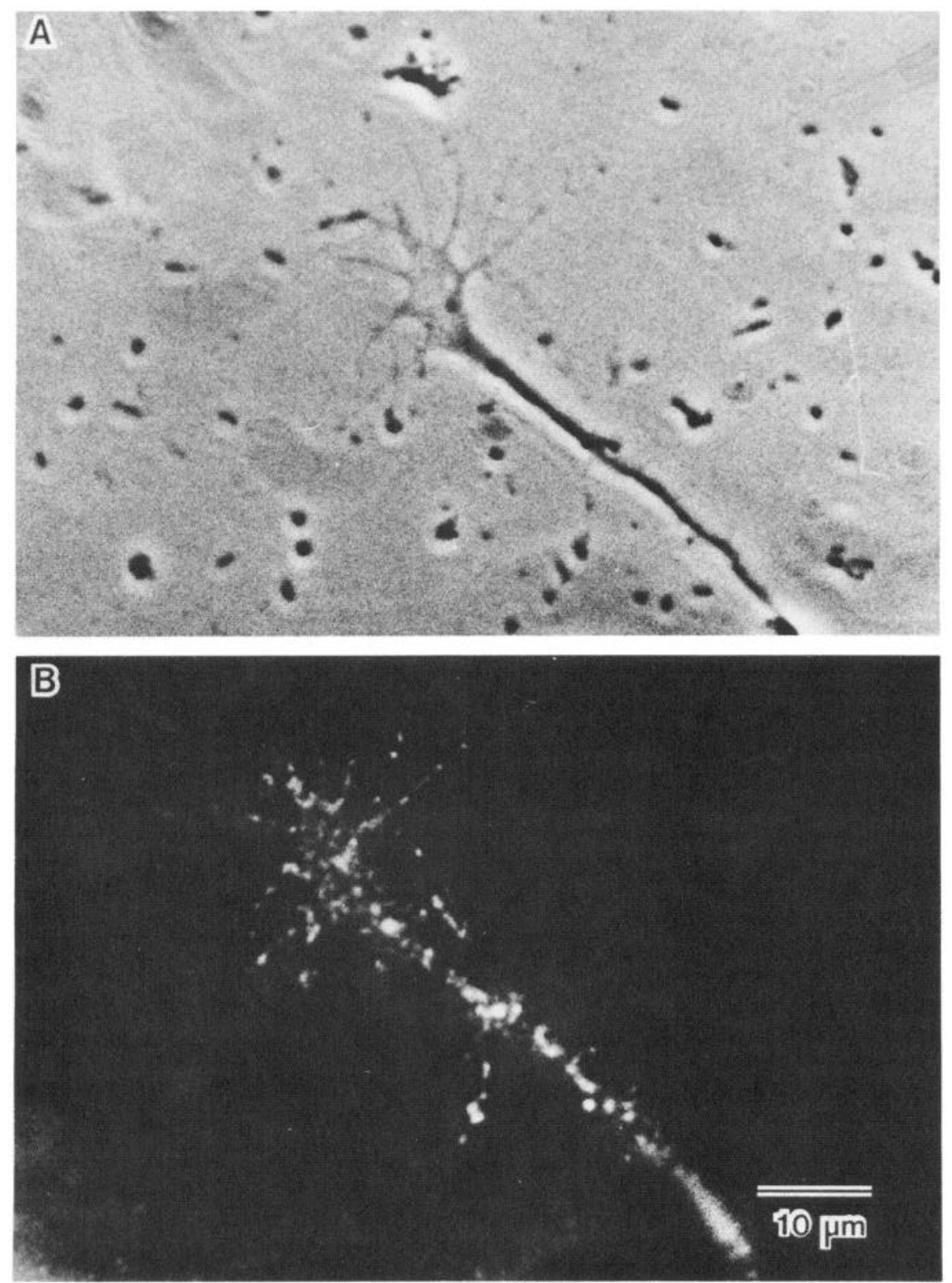

Figure 10. Localization of the CSAT antigen on the growth cone of a dorsal root ganglion neuron. Neurons were cultured for $16-20 \mathrm{hr}$ on poly-L-lysine and gelatin-coated Aclar, fixed, and exposed to a polyclonal antisera against the affinity-purified CSAT antigen. The polyclonal antibodies were detected using rhodamine-conjugated goat antirabbit $\mathrm{Fab}_{2}$ fragments. $A$, Phase contrast. $B$, Rhodamine optics. fibronectin is only partially inhibited by the CSAT Mab, and that of cardiac fibroblasts to fibronectin is not detectably inhibited. In contrast, the adhesion of both cell types to laminin is completely inhibited by the CSAT Mab. Two factors probably contribute to these cell type and substrate-dependent susceptibilities: (1) The oligomeric nature of the CSAT antigen and the sites of its interaction with different ligands and the CSAT Mab, and (2) the presence of additional adhesion mechanisms that do not contain the CSAT antigen (Decker et al., 1984; Horwitz et al., 1985). It seems likely that these explanations apply to the neurons as well.

The effects of the CSAT Mab described here complement those described for antibodies against N-CAM. These latter antibodies promote process extension and tend to inhibit axonal fasciculation, presumably by interfering with the neuron-neuron interactions mediated by N-CAM (Rutishauser et al., 1983). The CSAT Mab, in contrast, inhibits axonal extension and promotes fasciculation of neurites. This interplay between process outgrowth and fasciculation of neurites in relation to the interaction of neurons with the substratum had precedents in the work of Nakai (1960) and Letourneau (1975). Nakai related the adhesive potential between semisolid and solid substrates to the degree of neurite fasciculation and somal aggregation, and he found that a putatively less adhesive substrate promoted the highest degree of fasciculation and somal aggregation. Letourneau (1975), along with Rogers et al. (1983), explored the adhesive potential of several commonly used substrates with respect to the number and length of processes extended and found that there exist definite differences between substrates in their potential to support neurite outgrowth. The importance of fasciculation in neurite outgrowth is underscored by the recent work of Landmesser et al. (1983) and Goodman et al. (1984). Both demonstrated that neurites make choices to grow either along existing axonal trajectories, thus forming fascicles, or along other substrata. These choices are potentially complex phenomena with several potential points of regulation, including modulation in expression of the CSAT antigen, N-CAM (Thierry et al., 1985), substrate molecules, and recognition molecules that have not yet been identified.

How does the CSAT antigen participate in these phemonena? Our observations on fibroblasts and muscle have provided strong evidence that the antigen functions as a receptor for laminin, fibronectin, and perhaps other extracellular matrix molecules as well. It is also an attractive candidate for a transmembrane link 
that connects the cytoskeleton with the extracellular matrix. Several lines of evidence support this hypothesis. The CSAT antibody inhibits adhesion of cells to both laminin and fibronectin. It also perturbs their morphology when added to cells that are already spread. In fibroblasts, the antigen colocalizes with fibronectin in areas surrounding cell matrix adhesion sites at the termini of actin filaments in vinculin-rich areas (Damsky et al., 1985; Neff et al., 1982). On muscle cells, the antigen colocalizes with laminin in regions of high Ach receptor density (Bozyczko and Horwitz, 1985), a putative region of cell matrix adhesion. Finally, Horwitz et al. (1985) have used equilibrium gel filtration to show that the purified antigen forms complexes with fibronectin and laminin. The interaction with laminin is inhibited by the CSAT Mab, and that to fibronectin by synthetic sequences representing the cell-binding region of fibronectin. The association constants for these interactions compare well with those described for the binding of fibronectin and its fragments to cell surfaces. This antigen is similar in molecular weight to the fibronectin-binding molecule from a human cell line described by Pytela et al. (1985). In contrast, the molecular weight of this antigen is different from that of the laminin receptor described by others (Lesot et al., 1983; Malinoff and Wicha, 1983; Ráo et al., 1983).

The CSAT antigen is unique among molecules of the pcripheral nervous system that participate in neuronal-substrate interactions. It is the only adhesion molecule that functions in neurite outgrowth as an integral membrane component. The inhibition experiments presented here suggest that it plays a dominant role. Other neuritc outgrowth-promoting factors are extracellular and have been partially purified from conditioned media (Cole and Glaser, 1984a, b; Collins, 1978; Lander et al., 1985; Matthew et al., 1982). Many of these are active when bound to cationic substrates. Recently Lander et al. (1985) have isolatcd the active outgrowth-promoting factor in several conditioned media. It is an aggregate consisting of a heparin sulfate proteoglycan and two proteins, one of which is laminin and the other a $150 \mathrm{kDa}$ molecule presumed to be entactin. Because of the copurification of laminin with the active outgrowth-promoting factor, and in light of its neurite outgrowth-promoting activity when independently bound to substrates, laminin has been implicated as the active factor in conditioned media. These findings further substantiate the significance of the CSAT antigen in peripheral neurite extension since it likely serves as a receptor for the laminin found within the substrate-bound aggregates, thus facilitating the neuronal-substratum interaction.

\section{References}

Bentley, D., and M. Caudy (1983) Navigational substrates for peripheral pioneer growth cones: Limb-axis polarity cues, limb-segment boundaries, and guidepost neurons. Cold Spring Harbor Symp. Quant. Biol. 48: 573-585.

Bottenstein, J. E., S. D. Skaper, S. S. Varon, and G. H. Sato (1980) Selective survival of neurons from chick embryo sensory ganglionic dissociates utilizing serum-free supplemented medium. Exp.Cell Res. 125: 183-190.

Bozyczko, D., C. Decker, R. Greggs, and A. F. Horwitz (1984a) Identification of an antigen implicated in the adhesion of neurons to the extracellular matrix. J. Cell. Biochem. 8: 114 (abstract 1138).

Bozyczko, D., C. Decker, and A. F. Horwitz (1984b) A membrane antigen involved in neuronal-substratum adhesion. J. Cell Biol. 99: 431 (abstract 117a).

Bozyczko, D., and A. Horwitz (1985) An integral membrane glycoprotein complex that participates in axonal guidance and organization of the neuromuscular junction. Soc. Neurosci. 11:336 (abstract 102.12).

Buskirk, D. R., J.-P. Thiery, U. Rutishauser, and G. M. Edelman (1980) Antibodies to neural cell adhesion molecule disrupt histogenesis in cultured chick retinae. Nature 285: 488-489.

Chen, W. T., T. Hasegawa, C. Weinstock, and K. M. Yamada (1985) Development of cell surface linkage complexes in cultural fibroblasts. J. Cell Biol. 100: 1103-1114.
Cole, G. J., and L. Glaser (1984a) Inhibition of embryonic neural retina cell-substratum adhesion with a monoclonal antibody. J. Cell Biol. 259: 4031-4034.

Cole, G. J., and L. Glaser (1984b) Cell-substratum adhesion in embryonic chick central nervous system is mediated by a 170,000 -molwt neural-specific polypeptide. J. Cell Biol. 99: 1605-1612.

Cole, G. J., D. Schubert, and L. Glascr (1985) Ccll-substratum adhesion in chick neural retina depends upon protein-heparin sulfate interactions. J. Cell Biol. 100: 1192-1199.

Collins, F. (1978) Induction of neurite outgrowth by a conditionedmedium factor bound to the culture substratum. Proc. Natl. Acad. Sci. USA 75: 5210-5213.

Damsky, C., K. Knudsen, D. Bradley, C. Buck, and A. Horwitz (1985) Distribution of cell substratum attachment (CSAT) antigen on myogenic and fibroblastic cells in culture. J. Cell Biol. 100: 1528-1539.

Decker, C., R. Greggs, K. Duggan, J. Stubbs, and A. Horwitz (1984) Adhesive multiplicity in the interaction of embryonic fibroblasts and myoblasts with extracellular matrices. J. Cell Biol. 99: 1398-1404.

Edelman, G. M., S. Hoffman, C. M. Chuong, J.-P. Thiery, R. Brackenbury, W. J. Gallin, M. Grumet, M. E. Greenberg, J. J. Hemperly, C. Cohen, and B. A. Cunningham (1983) Structure and modulation of neural cell adhesion molecules in early and late embryogenesis. Cold Spring Harbor Symp. Quant. Biol. 48: 515-526.

Goodman, C. S., M. J. Bastiani, C. Q. Doe, S. du Lac, S. L. Helfand, J. Y. Kuwasa, and J. B. Thomas (1984) Cell recognition during neuronal development. Science 225: 1271-1279.

Greve, J. M., and D. I. Gottlieb (1982) Monoclonal antibodies which alter the morphology of cultured chick myogenic cells. J. Cell Biochem. 18: 221-230.

Grumet, M., and G. M. Edelman (1985) Heterotypic binding between neuronal membrane vesicles and glial cells is mediated by a specific neuronal-glial cell adhesion molecule. J. Cell Biol. 98: 1746-1756.

Grumet, M., U. Rutishauser, and G. M. Edelman (1982) Neural cell adhesion molecule is on embryonic muscle cells and mediates adhesion to nerve cells in vitro. Nature 295: 693-695.

Horwitz, A., K. Duggan, R. Greggs, C. Decker, and C. Buck (1985) The CSAT antigen has properties of a receptor for laminin and fibronectin. J. Cell Biol. 101: 2134-2144.

Knudsen, K., A. Horwitz, and C. Buck (1985) A monoclonal antibody identifies a glycoprotein complex involved in cell-substratum adhesion. Exp. Cell Res. 157: 218-226.

Lander, A. D., D. K. Fuji, and L. F. Reichardt (1985) Laminin is associated with the "neurite outgrowth-promoting factors" found in conditioned media. Proc. Natl. Acad. Sci. USA 82: 2183-2187.

Landmesser, L. T., M. J. Donovan, and M. Honig (1983) The response of avian hindlimb motor and sensory neurons to an altered periphery. In Limb Development and Regeneration, Pt. A, J. Fallon and A. Caplan, eds., pp. 207-216, Alan R. Liss, NY.

Lesot, H., U. Kuhl, and K. Von der Mark (1983) Isolation of a lamininbinding protein from muscle cell membranes. EMBO J. 2: 861-865.

Letourneau, P. C. (1975) Cell-to-substratum adhesion and guidance of axonal elongation. Dev. Biol. 44: 92-101.

Malinoff, H. L., and M. S. Wicha (1983) Isolation of a cell surface receptor for laminin from murine sarcoma cells. J. Cell Biol. 96: 14751479.

Manthorpe, M., E. Engvall, E. Ruoslahti, F. M. Longo, G. E. Davis, and S. Varon (1983) Laminin promotes neuritic regeneration from cultured peripheral and central neurons. J. Cell Biol. 97: 1882-1890.

Matthew, W. D., A. D. Lander, R. J. Greenspan, and L. F. Reichardt (1982) A heparin sulfate proteoglycan on the surface on neurons in vivo is associated with a potent inducer of in vitro neurite outgrowth. Soc. Neurosci. Abstr. 8: 834.

Nakai, J. (1960) Studies on the mechanism determining the course of nerve fibers in tissue culture. II. The mechanism of fasciculation. $Z$. Zeffforsch. Anat. 52: 427-449.

Neff, N. T., C. Lowrey, C. Decker, A. Tovar, C. Damsky, C. Buck, and A. F. Horwitz (1982) A monoclonal antibody detaches embryonic skeletal muscle from extracellular matrices. J. Cell Biol. 95: 654-666.

Parham, P. (1983) The fragmentation of monoclonal IgG1, IgG2a and IgG2b from Balb/c mice. J. Immunol. 131: 2895-2902.

Pytela, R., M. Pierschbacker, and E. Rouslahti (1985) Identification disolation of a $140 \mathrm{kd}$ cell surface glycoprotein with properties of a fibronectin receptor. Cell 40: 191-198.

Ráo, N. C., S. H. Barsky, V. P. Terranova, and L. A. Liotta (1983) Isolation of a tumor cell laminin receptor. Biochem. Biophys. Res. Commun. 111: 804-808. 
Raper, J. A., M. J. Bastiani, and C. Goodman (1983) Guidance of neuronal growth cones: Selective fasciculation in the grasshopper embryo. Cold Spring Harbor Symp. Quant. Biol. 48: 587-598.

Rogers, S. L., P. C. Letourneau, S. L. Palm, J. McCarthy and L. T. Furcht (1983) Neurite extension by peripheral and central nervous system neurons in response to substratum-bound fibronectin and laminin. Dev. Biol. 98: 212-220.

Rogers, S. L., J. B. McCarthy, S. L. Palm, L. T. Furcht, and P. C. Letourneau (1985) Neuron-specific interactions with two neuritepromoting fragments of fibronectin. I. Neurosci. 5: 369-378.

Rutishauser, U. (1983) Molecular and biological properties of a neural cell adhesion molecule. Cold Spring Harbor Symp. Quant. Biol. 48. 501-514.

Rutishauser, U., and G. M. Edelman (1980) Effects of fasciculation on the outgrowth of neurites from spinal ganglia in culture. J. Cell Biol. 87: 370-378.

Rutishauser, U., W. E. Gall, and G. M. Edelman (1978) Adhesion among neural cells of the chick embryo. IV. Role of the cell surface molecule CAM in the formation of neurite bundles in cultures of spinal ganglia. J. Cell Biol. 79: 382-393.

Rutishauser, U., M. Grumet, and G. M. Edelman (1983) Neural cell adhesion molecule mediates initial interactions between spinal cord neurons and muscle cells in culture. J. Cell Biol. 97: 145-152.

Schachner, M., A. Faissner, J. Krusse, J. Lindner, D. H. Meier, F. O. Rathjen, and H. Wernecke (1983) Cell-type specificity and developmental expression of neural cell-surface components involved in cell interactions and of structurally related molecules. Cold Spring Harbor Symp. Quant. Biol. 48: 557-568.

Schubert, D., M. LaCorbiere, F. G. Klier, and C. Birdwell (1983) A role for adherons in neural retina cell adhesion. J. Cell Biol. 96: 990998.

Stirling, R. V., and D. Summerbell (1983) Familiarity breeds contempt: The behavior of axons in foreign and familiar environments In Limb Development and Regeneration, Part A, J. Fallon and A. Caplan, eds., pp. 217-226, Alan R. Liss, NY.

Thanos, S., F. Bonhoeffer, and U. Rutishauser (1984) Fiber-fiber interaction and tectal cues influence the development of the chicken retinotectal projection. Proc. Natl. Acad. Sci. USA 81: 1906-1910.

Thiery, J.-P., A. Delouveé, M. Grumet, and G. M. Edelman (1985) Initial appearance and regional distribution of the neuron-glia adhesion molecule in the chick embryo. J. Cell Biol. 100: 442-456. 